\title{
Pathogenesis of "Senile" Nodular Sclerosis of Atrio-ventricular Valves
}

\author{
ARIELA POMERANCE` \\ From the Department of Histopathology, Central Middlesex Hospital, London N.W. 10
}

Nodular thickening of the atrio-ventricular valves may be conspicuous in the hearts of the elderly. Usually described as senile sclerosis, it is assumed to be an involutional or degenerative process associated with advanced age. The difficulty of distinguishing such changes from the results of other pathological conditions which may have been present earlier in life is well recognized (Gould, 1960), and some workers attribute these changes to processes other than simple ageing. Robbins (1962) included senile sclerosis as a facet of arteriosclerotic heart disease; Rezek and Millard (1963) considered it was due to previous non-specific endocarditis; and Angrist (1964) thought both these processes played a part. In the present study, necropsy material from 815 patients was examined in an attempt to evaluate the possible roles of inflammation, ageing, atheroma, hypertension, and cardiac hypertrophy in the pathogenesis of nodular sclerosis.

\section{SUBJECTS AND METHODS}

Over a period of $2 \frac{1}{2}$ years the hearts of all patients over 10 years coming to necropsy in this hospital were examined in detail before fixation. Particular attention was paid to the site, degree and nature of valvular thickening, lipoid infiltrations, scarring, and calcification. Hearts with other macroscopical pathology of the atrio-ventricular valves were excluded from the present study.

Thickening of the atrio-ventricular valves was graded as absent, slight, moderate, or marked (Fig. 1), by inspection and palpation; and lipoid deposition (atheromatosis) in the anterior cusp of the mitral valve similarly was graded visually. All observations were made by the same observer and the results were reproducible while the hearts remained unfixed. No reliable macroscopical assessment of thickening could be made on fixed valves.

\footnotetext{
Received January 11, 1966.

$\star$ In receipt of a grant from the North West Metropolitan Regional Hospital Board.
}

The hearts from all patients under 30 or over 80 years were fixed in formol-saline, together with representative samples of each intermediate age-group, and material was selected for microscopy after 5-15 days of formalin fixation. This included at least one block through each cusp of the atrio-ventricular valves, with adjacent tissues. Sections were stained with hæmatoxylin and eosin, and Weigert's elastic-van Gieson method. Heart weight, estimations of the degree of coronary and aortic atheroma, and details of pathological findings in other systems were obtained as part of the normal necropsy routine, and clinical data were abstracted from case notes. All observations and information were recorded on a punch-card system.

\section{RESULTS}

There were 815 hearts which were suitable for inclusion in this study. The age and sex distribution is shown in Table $\mathrm{I}$.

TABLE I

AGE AND SEX DISTRIBUTION OF 815 HEARTS EXAMINED

\begin{tabular}{l|r|r|r|r|r|r|r|r|r}
\hline $\begin{array}{c}\text { Age-group } \\
\text { (yr.) }\end{array}$ & $0-15$ & $15-24$ & $25-34$ & $35-44$ & $45-54$ & $55-64$ & $65-74$ & $75-84$ & $85-94$ \\
\hline Men & 1 & 3 & 8 & 13 & 38 & 84 & 100 & 114 & 59 \\
Women & 0 & 2 & 3 & 19 & 35 & 65 & 75 & 118 & 78 \\
\hline Total & 1 & 5 & 11 & 32 & 73 & 149 & 175 & 232 & 137 \\
\hline
\end{tabular}

Pathology. All adult mitral valves showed at least a slight degree of nodular thickening of the anterior cusp. The earliest lesion consisted of localized plaques on the atrial surface, over the insertions of the chordæ tendineæ. With increasing severity these plaques increased in thickness and area, eventually coalescing (Fig. 1), but remained confined to the zone of apposition of the cusp. The tricuspid valve was uniformly thin and translucent (Fig. 1) in the majority of patients under 55 years, and remained so in 20 per cent of those over 85 

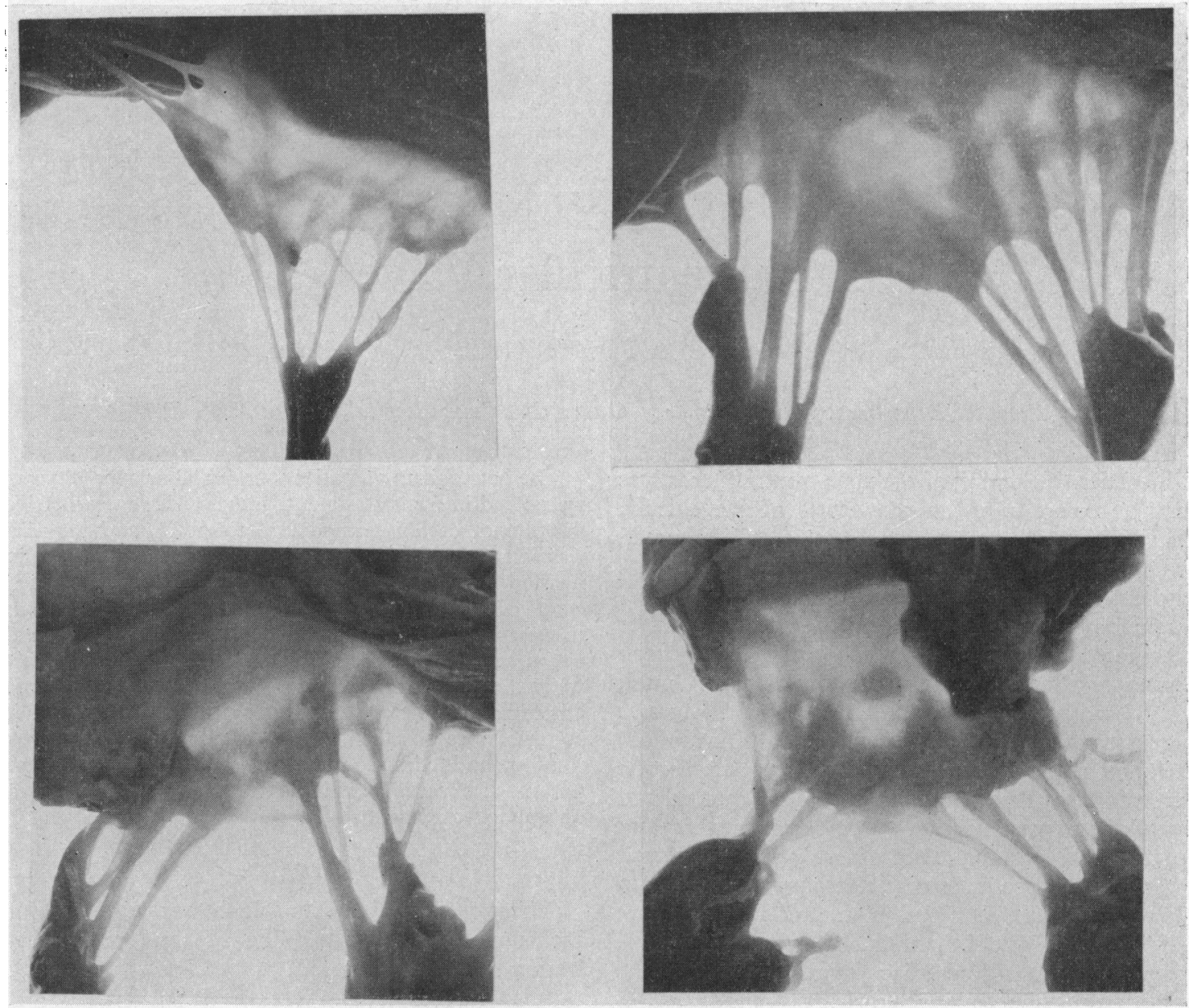

FIG. 1.-Transilluminated anterior cusps of atrio-ventricular valves, to show grades of nodular thickening. ( $\times 1 \frac{1}{2}$ approx.). Top left - a thin translucent tricuspid cusp from a woman aged 68 with systemic hypertension for 10 years, and normal respiratory system. Top right-slight nodular thickening over the chordæ tendineæ insertions of a mitral cusp. The more proximal opacities are areas of atheromatosis. From a woman aged 49 with acromegaly and severe hypertension; the heart weighed $900 \mathrm{~g}$. Bottom left-moderate nodular thickening of mitral cusp. From a woman aged 67 without cardiac or respiratory disease. Bottom right-marked nodular thickening of mitral cusp. Although confluent, the plaques are limited to the zone of apposition with the posterior cusp. From a man aged 53 with pulmonary fibrosis, emphysema and bronchiectasis.

years. Nodular thickening involved mainly the anterior cusp of this valve also, and developed as in the mitral valve.

Microscopically, the plaques consisted of localized foci of collagenous thickening (Fig. 2) in the endocardium of the atrial surface (atrialis), with variable but mainly scanty fine elastic fibrils. The normally well-defined elastic lamina at the base of the atrialis often showed localized fraying or fragmentation under the collagenous plaques. Active endothelial damage was not seen, neither was there any evidence of old or recent inflammatory changes. The layers of the cusp retained their anatomical relations, no vessels were seen, and there was no inflammatory cell infiltration. Lipoid infiltration was occasionally seen but only in the oldest patients, and always on the ventricular aspect of the cusp. No lipoid was demonstrated in the thickened plaques of the atrial surface.

Relation of Nodular Thickening to Ageing. This differed in each sex and in mitral and tricuspid valves, but very little progressive thickening occurred in the oldest groups. In men, mitral valve 

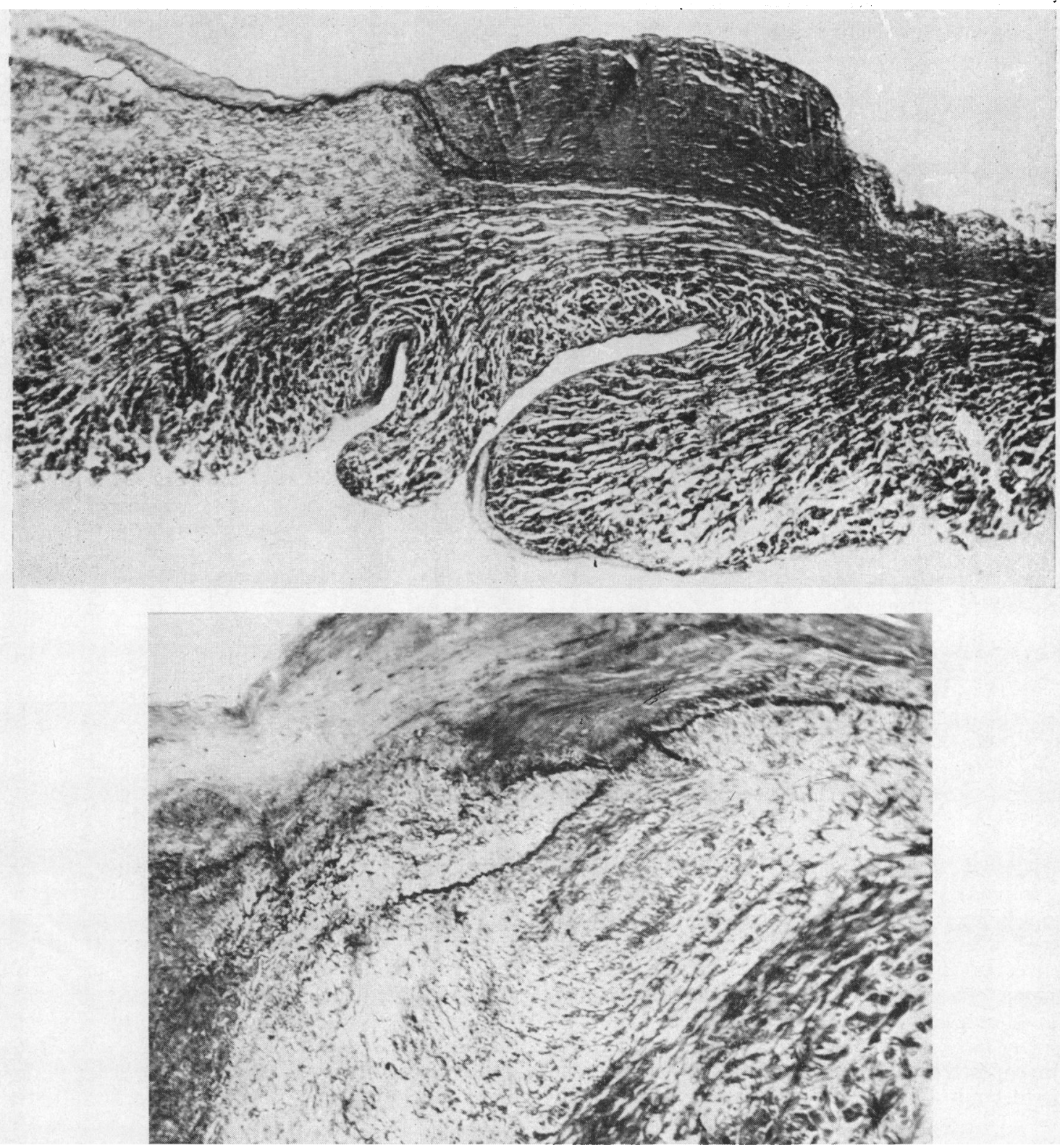

FIg. 2. Top-Section through an area of slight nodular thickening, showing the collagenous plaque in the atrialis and fraying of the underlying elastic lamina. (Weigert's Elastic-van Gieson. $\times 40$ ). Bottom-Higher magnification $(\times 75)$ of elastic fragmentation underlying a plaque of nodular thickening.

thickening increased with age, but most of this occurred in the under 65-year groups (Fig. 3). Tricuspid valve thickening also showed a similar increase during middle age, continuing through the 65-74 year group.

In women, the tricuspid valve changes with age were similar to those in men, though women under
45 years had a greater incidence of moderate and marked thickening than those between 45 and 54 years. The mitral valve changes were not related to age. The highest proportions of moderate and marked thickening were seen in the 65- to 74-year group, but these differed only slightly from those in women under 45 or over 85 years (Fig. 4). 

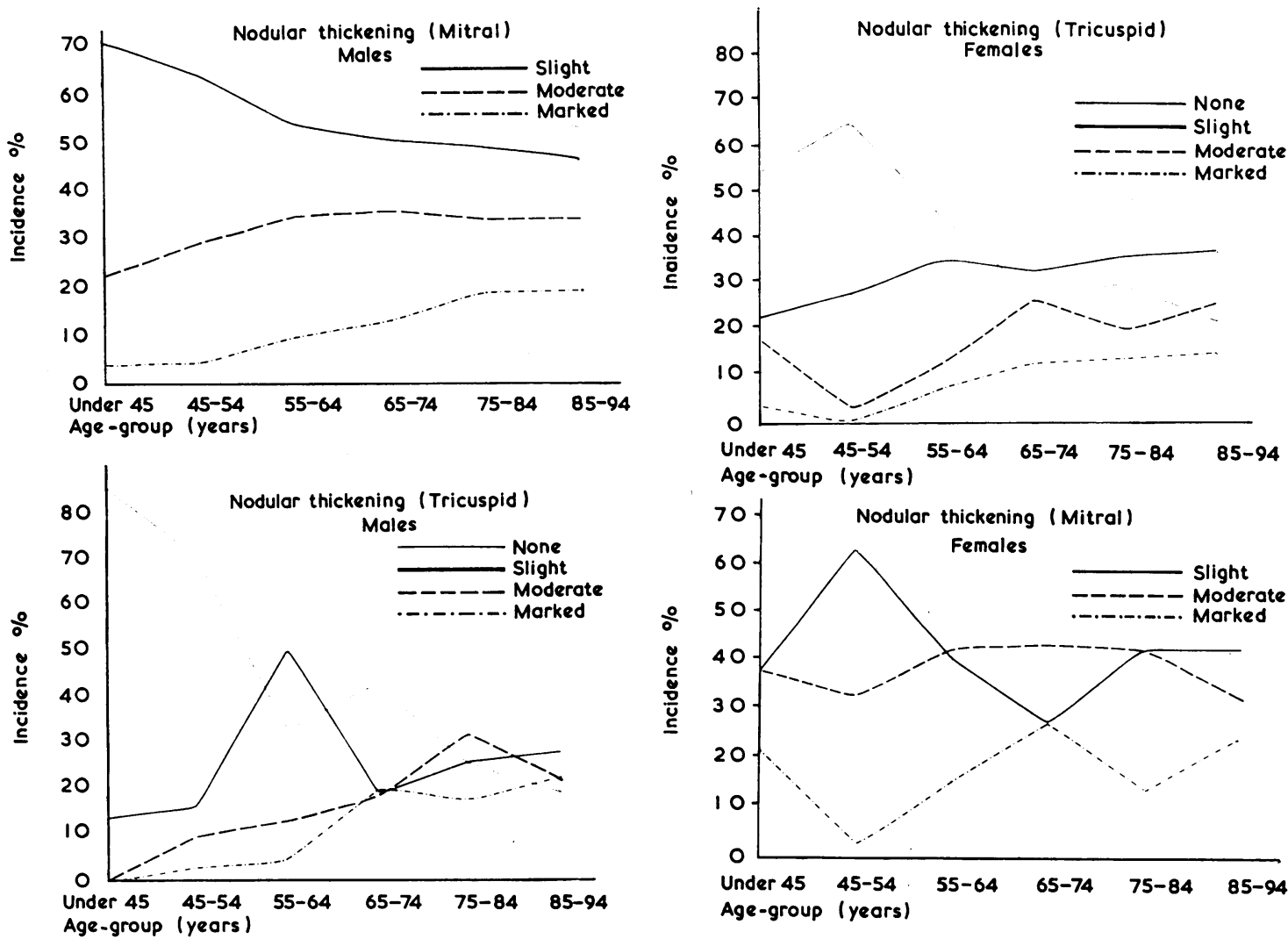

FIG. 3.-Relation between age and degree of mitral and tricuspid valve thickening in men.

Normal Ageing Changes. From the above results it is possible to define a standard for the normal appearances of the atrio-ventricular valves in the aged. Gavey's (1949) criteria for normal heart valves in any age-group as "the least degree of change observed in that group" has been applied. As 44 per cent of hearts, even in the over 85-year group, had only slight mitral valve thickening, and tricuspid thickening was absent in 20 per cent, the normal mitral valve should, therefore, show only

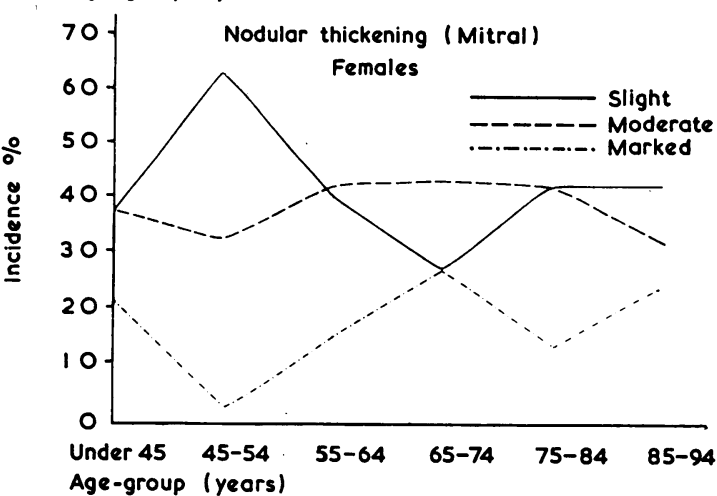

FIG. 4.-Relation between age and degree of mitral and tricuspid valve thickening in women.

slight nodular sclerosis, even in the elderly, and the normal tricuspid valve none. These findings agree with Gavey's, and with those of Rosenthal and Feigin (1947), who were also studying mitral valve changes with no pre-existing standard for normal valvular thickening.

Relation of Nodular Thickening to Systemic Hypertension and Other Hyperkinetic States. Differences noted between the valves of each side of the heart (Robbins, 1962; McMillan and Lev, 1964)

TABLE II

RELATION OF NODULAR THICKENING OF THE ANTERIOR MITRAL CUSP AND SYSTEMIC HYPERTENSION

\begin{tabular}{|c|c|c|c|c|c|c|}
\hline \multirow{2}{*}{$\begin{array}{l}\text { Degree of } \\
\text { thickening }\end{array}$} & \multicolumn{2}{|c|}{ All cases } & \multicolumn{2}{|c|}{ Men } & \multicolumn{2}{|c|}{ Women } \\
\hline & Hypertensive & Not hypertensive & Hypertensive & Not hypertensive & Hypertensive & Not hypertensive \\
\hline \multirow[t]{2}{*}{$\begin{array}{l}\text { Slight } \\
\text { Moderate } \\
\text { Marked }\end{array}$} & $\begin{array}{l}41(41 \%) \\
38(38 \%) \\
21(21 \%)\end{array}$ & $\begin{array}{l}312(47 \cdot 5 \%) \\
241(37.5 \%) \\
100(15 \%)\end{array}$ & $\begin{array}{l}21(52 \%) \\
11(28 \%) \\
8(20 \%)\end{array}$ & $\begin{array}{r}185(52 \%) \\
120(35 \%) \\
47(13 \%)\end{array}$ & $\begin{array}{l}20(33 \%) \\
27(45 \%) \\
13(22 \%)\end{array}$ & $\begin{array}{l}128(42 \%) \\
121(40 \%) \\
54(18 \%)\end{array}$ \\
\hline & \multicolumn{2}{|c|}{$\begin{array}{l}\chi^{2}=2.75 ; \mathrm{n}=2 ; \mathrm{p}>0.2 \text { (not significant) } \\
\text { After standardization for age and sex } \\
\chi^{2}=1.24 ; \text { and } \mathrm{p}>0.5\end{array}$} & & & & \\
\hline
\end{tabular}


suggested that excessive thickening might be determined by hypertension. Comparison of mitral valves in patients with and without systemic hypertension showed an increased incidence of marked nodular thickening in the hypertensives, particularly in men (Table II). This difference was not statistically significant, however, confirming the impression obtained from observations on individual patients (e.g. Fig. 1 top), that systemic hypertension did not influence the degree of mitral sclerosis.

As the intensity of the first heart sound is an indication of the force with which the atrio-ventricular cusps appose (Wood, 1962), the degree of mitral valve thickening in some conditions associated with an increased first sound was examined. The three thyrotoxic patients showed one example each of slight, moderate, and marked thickening. Anæmia, pyrexia, exertion, and emotional excitement had been present for too brief a time to have affected the valves. The altered hæmodynamics of pregnancy are maintained for long enough to merit investigation, but, though the only woman under 35 years with marked nodular sclerosis had five children, there was no excess of women with three or more children in the marked mitral thickening group ( $8 \%$, compared with $12 \%$ of those with slight and moderate thickening).

Relation of Nodular Thickening to Chronic Pulmonary Disease. Quantitative studies of pulmonary vascular pressure were not practicable in this series, but comparison of the anterior tricuspid cusp changes in patients with and without chronic pulmonary disease showed a highly significant increase in thickening in the former group. This was still present after standardization for age and sex (Table III and Fig. 5). Since almost all the 84 cases were patients with chronic bronchitis, and right ventricular hypertrophy at necropsy, it seemed likely that the increased tricuspid thickening was related to pulmonary hypertension.

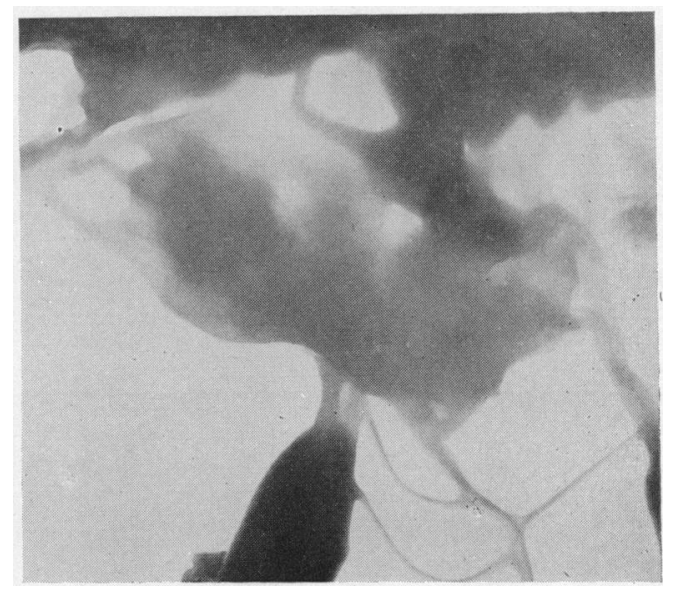

FIG. 5.-Transilluminated anterior cusp of a tricuspid valve showing conspicuous nodular thickening, from a woman aged 56 with bronchial asthma. ( $\times 1 \frac{1}{2}$ approx.).

Correlation Between Nodular Thickening of Mitral and Tricuspid Valves. Comparison of the degree of tricuspid thickening present in cases with and without marked mitral thickening showed an almost threefold increase in marked tricuspid thickening in the former group (Table IV). This was no longer apparent when the cases of chronic pulmonary disease were excluded, and it therefore appeared likely that the degree of mitral thickening, as well as tricuspid thickening, might be related to pulmonary disease. Comparison of mitral valve changes in

\section{TABLE IV}

COMPARISON OF DEGREE OF NODULAR THICKENING OF ANTERIOR TRICUSPID CUSP IN PATIENTS WITH AND WITHOUT MARKED MITRAL THICKENING

\begin{tabular}{l|c|c}
\hline \multicolumn{1}{c|}{$\begin{array}{c}\text { Degree of } \\
\text { tricuspid } \\
\text { thickening }\end{array}$} & $\begin{array}{c}\text { Marked mitral } \\
\text { thickening }\end{array}$ & Remaining patients \\
\hline None & $21(21 \%)$ & $268(39 \%)$ \\
Slight & $28(27 \%)$ & $219(32 \%)$ \\
Moderate & $25(24 \%)$ & $128(19 \%)$ \\
Marked & $29(28 \%)$ & $70(10 \%)$ \\
\hline
\end{tabular}

TABLE III

RELATION BETWEEN NODULAR THICKENING OF THE ANTERIOR TRICUSPID CUSP AND CHRONIC PULMONARY DISEASE

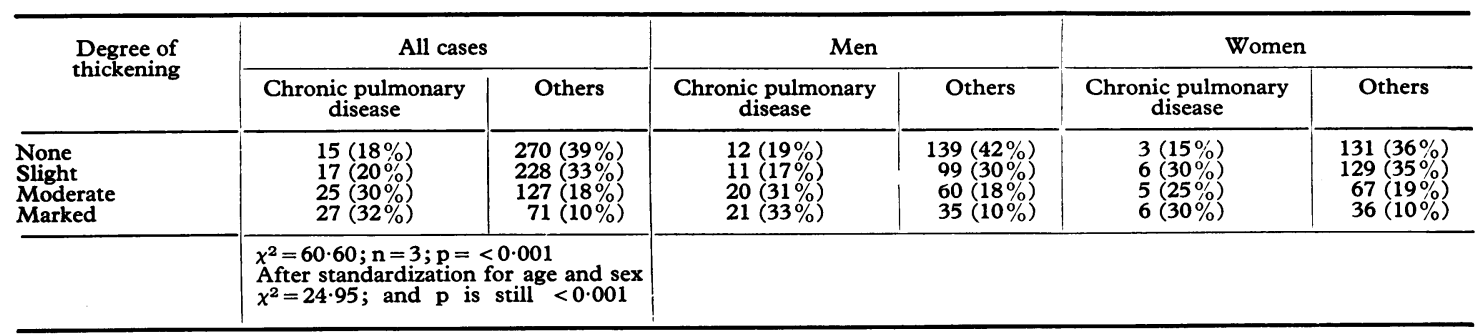


TABLE V

RELATION BETWEEN NODULAR THICKENING OF THE ANTEROIR MITRAL CUSP AND CHRONIC PULMONARY DISEASE

\begin{tabular}{|c|c|c|}
\hline $\begin{array}{l}\text { Degree of mitral } \\
\text { nodular thickening }\end{array}$ & $\begin{array}{l}\text { Chronic pulmonary } \\
\text { disease patients }\end{array}$ & Remaining patients \\
\hline \multirow[t]{2}{*}{$\begin{array}{l}\text { Slight } \\
\text { Moderate } \\
\text { Marked }\end{array}$} & $\begin{array}{l}31(34 \%) \\
40(43 \%) \\
21(23 \%)\end{array}$ & $\begin{array}{r}323(50 \%) \\
226(35 \%) \\
99(15 \%)\end{array}$ \\
\hline & \multicolumn{2}{|c|}{$\begin{array}{l}\chi^{2}=8.87 \mathrm{n}=2 \text { and } \mathrm{p}=<0.02 \\
\text { After standardization for age and sex } \\
\chi^{2}=7.74 \text { and } \mathrm{p} \text { remains }<0.02\end{array}$} \\
\hline
\end{tabular}

patients with and without chronic pulmonary disease confirmed this (Table V), and the correlation remained statistically significant after standardization for age and sex.

Relation of Nodular Thickening to Heart Size. The possibility that the severity of valvular thickening was merely an expression of generalized cardiac hypertrophy or atrophy from any cause was examined. There was no difference in the incidence of each degree of nodular thickening in hearts weighing under $300 \mathrm{~g}$. (Table VI), but a considerable excess of cases with moderate and marked mitral thickening in those over $450 \mathrm{~g}$. (Table VII). However, after standardization for age and sex, this correlation was not significant.

Relation of Nodular Thickening to Atheroma. The blood vessels of the atrio-ventricular valves arise from the coronary arteries (Clarke, 1965), and if nodular sclerosis is a manifestation of athero-
TABLE VIII

RELATION BETWEEN NODULAR THICKENING OF ANTERIOR MITRAL CUSP AND MYOCARDIAL INFARCTION

\begin{tabular}{l|l|l}
\hline $\begin{array}{c}\text { Degree of } \\
\text { thickening }\end{array}$ & $\begin{array}{c}\text { Myocardial } \\
\text { infarction }\end{array}$ & $\begin{array}{c}\text { No myocardial } \\
\text { infarction }\end{array}$ \\
\hline Slight & $56(46 \%)$ & $298(46.5 \%)$ \\
Moderate & $47(38.5 \%)$ & $236(37 \%)$ \\
Marked & $19(15.5 \%)$ & $105(16.5 \%)$ \\
\hline
\end{tabular}

sclerosis, a correlation with the degree of coronary atherosclerosis should be present. Comparison of the degree of nodular thickening of the mitral valve in patients with and without myocardial infarction showed no differences (Table VIII), and comparison of the degrees of coronary atherosclerosis in

TABLE IX

COMPARISON OF DEGREE OF CORONARY ATHEROMA IN PATIENTS WITH AND WITHOUT MARKED THICKENING OF ANTERIOR MITRAL CUSP

\begin{tabular}{l|c|c}
\hline $\begin{array}{c}\text { Degree of } \\
\text { coronary atheroma }\end{array}$ & $\begin{array}{c}\text { Marked mitral } \\
\text { thickening }\end{array}$ & Remaining patients \\
\cline { 1 - 2 } None or slight & $43(44 \%)$ & $218(43 \%)$ \\
Moderate & $33(33 \%)$ & $175(35 \%)$ \\
Marked & $23(23 \%)$ & $113(22 \%)$ \\
\hline
\end{tabular}

patients with marked mitral valve thickening and those with moderate and slight thickening (Table IX) also failed to show any relation. This is not surprising, since the part of the valve affected by nodular sclerosis is normally avascular (Clarke,

TABLE VI

RELATION BETWEEN NODULAR THICKENING OF ANTERIOR MITRAL CUSP AND HEART WEIGHT, IN SMALL HEARTS

\begin{tabular}{|c|c|c|c|c|c|c|}
\hline \multirow{2}{*}{$\begin{array}{l}\text { Degree of } \\
\text { thickening }\end{array}$} & \multicolumn{2}{|c|}{ All cases } & \multicolumn{2}{|c|}{ Men } & \multicolumn{2}{|c|}{ Women } \\
\hline & $<300 \mathrm{~g}$ & $\underset{\text { hearts }}{\text { Remaining }}$ & $<300 \mathrm{~g}$ & $\begin{array}{c}\text { Remaining } \\
\text { hearts }\end{array}$ & $<300 \mathrm{~g}$ & $\underset{\text { hearts }}{\text { Remaining }}$ \\
\hline $\begin{array}{l}\text { Slight } \\
\text { Moderate } \\
\text { Marked }\end{array}$ & $\begin{array}{l}82(48 \%) \\
62(36.5 \%) \\
26(15.5 \%)\end{array}$ & $\begin{array}{r}264(47 \%) \\
215(37 \%) \\
94(16 \%)\end{array}$ & $\begin{array}{r}27(44 \%) \\
27(44 \%) \\
7(12 \%)\end{array}$ & $\begin{array}{r}174(53 \%) \\
108(33 \%) \\
45(14 \%)\end{array}$ & $\begin{array}{l}55(50 \%) \\
35(33 \%) \\
19(17 \%)\end{array}$ & $\begin{array}{r}90(37 \%) \\
107(43 \%) \\
49(20 \%)\end{array}$ \\
\hline
\end{tabular}

TABLE VII

RELATION BETWEEN NODULAR THICKENING OF ANTERIOR MITRAL CUSP AND HEART WEIGHT, IN LARGE HEARTS

\begin{tabular}{|c|c|c|c|c|c|c|}
\hline \multirow{2}{*}{$\begin{array}{l}\text { Degree of } \\
\text { thickening }\end{array}$} & \multicolumn{2}{|c|}{ All cases } & \multicolumn{2}{|c|}{ Men } & \multicolumn{2}{|c|}{ Women } \\
\hline & $>450 \mathrm{~g}$ & Remaining hearts & $>450 \mathrm{~g}$ & Remaining hearts & $>450 \mathrm{~g}$ & Remaining hearts \\
\hline \multirow[t]{2}{*}{$\begin{array}{l}\text { Slight } \\
\text { Moderate } \\
\text { Marked }\end{array}$} & $\begin{array}{l}59(40 \%) \\
57(38 \%) \\
34(22 \%)\end{array}$ & $\begin{array}{r}285(49 \%) \\
211(36 \%) \\
86(15 \%)\end{array}$ & $\begin{array}{l}49(49 \%) \\
37(37 \%) \\
19(19 \%)\end{array}$ & $\begin{array}{l}155(55 \cdot 5 \%) \\
89(32 \cdot 5 \%) \\
35(12 \%)\end{array}$ & $\begin{array}{l}18(28.5 \%) \\
20(41 \%) \\
16(30.5 \%)\end{array}$ & $\begin{array}{r}134(43 \%) \\
128(40 \%) \\
54(17 \%)\end{array}$ \\
\hline & \multicolumn{2}{|c|}{$\begin{array}{l}\chi^{2}=9.52 ; \mathrm{n}=2 ; \mathrm{p}=<0.01 ; \text { but after } \\
\text { standardization for age and sex } \\
\chi^{2}=4.94 ; \text { and } \mathrm{p}=>0.05\end{array}$} & & & & \\
\hline
\end{tabular}


1965). Although there was no correlation between nodular thickening and coronary disease, there appeared to be an association with the degree of lipoid infiltration (atheromatosis) of the proximal part of the ventricular surface of the cusp (Table X). Patients with marked mitral nodular sclerosis also had an increased incidence of marked mitral atheromatosis, and this was statistically significant after standardization for age and sex.

\section{TABLE X}

COMPARISON OF DEGREE OF MITRAL ATHEROMATOSIS IN PATIENTS WITH AND WITHOUT MARKED THICKENING OF ANTERIOR MITRAL CUSP

\begin{tabular}{l|c|c}
\hline $\begin{array}{c}\text { Degree } \\
\text { of mitral } \\
\text { atheromatosis }\end{array}$ & Marked mitral thickening & $\begin{array}{c}\text { Remaining } \\
\text { patients }\end{array}$ \\
\hline $\begin{array}{l}\text { None or slight } \\
\text { Moderate }\end{array}$ & $\begin{array}{c}22(21 \%) \\
\text { Marked }\end{array}$ & $\begin{array}{c}264(42 \%) \\
22(21 \%)\end{array}$ \\
\hline & $\begin{array}{c}302(49 \%) \\
59(9 \%)\end{array}$ \\
\hline & $\begin{array}{l}\chi^{2}=19 \cdot 0 ; \mathrm{n}=2 ; \mathrm{p}=<0.001 \\
\text { After standardization for age }\end{array}$ & \\
& And sex $\chi^{2}=13.95 ;$ and p re- \\
& mains $<0.001$ & \\
\hline
\end{tabular}

\section{Discussion}

The findings in the present study do not support views that "senile" sclerosis of atrio-ventricular valves is due to previous inflammation, atherosclerosis, or involutionary changes; they confirm the suggestion by McMillan and Lev (1964) that normal valve movement is responsible for the nodular thickenings.

Although post-inflammatory deformities are more common on the left side (Lepeschkin, 1952), like nodular sclerosis, and the localization of endocarditis on the line of valve closure is also determined by hæmodynamic factors (Rodbard, 1963; Lepeschkin, 1952), there was no histological evidence of previous endocarditis in the plaques of nodular sclerosis. These appeared to be a proliferative thickening localized to the atrialis, the anatomical layers remained distinct, and there was no associated vascularization or inflammatory cell infiltration. They did not contain lipoid or show calcification, as would be expected in atherosclerotic lesions, and were not related to coronary atherosclerosis. Since the impact on closing is sufficiently forceful to be audible as the first heart sound (Dock, 1945), the histological demonstration of localized damage to elastica (Fig. 2) at sites of greatest tension (i.e. over the chordæ tendineæ insertions) is not surprising. McMillan and Lev (1964) thought that the plaques were due to tensing of the chordx resulting in elastic proliferation opposite their insertions, but elastic proliferation was not a striking finding in the present series. The author considers that these plaques are a response to repeated trauma, analogous to cutaneous callus formation.

The observations on changes in nodular sclerosis with age indicate that "senile sclerosis" is a misleading term since the abnormal degree of thickening generally implied by this description is as likely to be found in a middle-aged patient as in a senile one, and the slight degree of nodularity which is normal in the aged was also present in all patients over 20 years. If involutionary changes are responsible for excessive nodular thickening, this condition should continue to develop in the elderly at least at the same rate as in middle age, and the finding that very little progressive increase in severity occurred in the older groups therefore indicates that senility is not responsible for "senile" valvular sclerosis.

The pathogenesis of excessive nodular thickening is not clear. It is possible that the increase throughout middle age is the result of cumulative mechanical stress, and the lack of further development in old age is due to the chemical changes in valve collagen which occur in the elderly (Verzár and Thoenen 1960; Angrist, 1964). However, the wide range in degrees of thickening between people of the same age-group indicates that individually variable factors must be concerned. A similar unexplained variability has been noted in monkeys (Lapin and Yakovleva, 1963). The importance of genetic factors in determining life span and cardiovascular disease is well known, and the reactivity of the valve endocardium may also be genetically determined. It was not possible to test this hypothesis in the present investigation.

The changes in degree of nodular thickening with age in men parallels the changes in blood pressure observed by Master, Lasser, and Jaffe (1958), and the differences between the valves of each side of the heart, also observed by previous workers (Robbins, 1962; McMillan and Lev, 1964), suggested that blood pressure might influence the degree of thickening. The increased incidence of tricuspid thickening in patients dying with chronic chest disease indicated that this was likely to be so in the pulmonary circulation, and similar tricuspid changes noted by Dmitrieva (1961) in patients with rheumatic mitral stenosis or pulmonary fibrosis and emphysema, are confirmatory findings.

There was, however, no correlation between systemic hypertension and the degree of mitral thickening, and increased closing force of the mitral valve also appeared unrelated to increased thickening, though there were too few examples of diseases 
associated with accentuated first heart sounds for reliable assessment. Anæmia and pyrexia were common but their duration was insufficient to produce valve sclerosis. Cumulative effects from the altered hæmodynamics of pregnancy might have accounted for the lack of correlation between age and degree of thickening found only in mitral valves in women, but multiparity was not associated with increased thickening. The possibility that increased valvular sclerosis was a facet of generalized cardiac hypertrophy was also considered, but no association with heart size was found. Most of the hearts over $450 \mathrm{~g}$. were from hypertensive or ischæmic heart disease cases, and this finding was, therefore, additional evidence against hypertension and arteriosclerosis as factors responsible for excessive nodular thickening.

As well as the absence of any quantitative or histological evidence for Robbins' (1962) view, an atherosclerotic pathogenesis for sclerosis of atrioventricular valves seems unlikely on anatomical grounds, as the relevant part of the valve is avascular (Clarke, 1965). Lipoid deposition does occur in the anterior cusp of the mitral valve but proximally (Fig. 1) and on the ventricular surface. Although there was a significant correlation between the severity of this condition and mitral valve thickening, it is difficult to envisage a causative relation. Since normal degrees of both conditions appear to be due to the same hæmodynamic factors (Pomerance, 1966, 1967), it is more probable that any factor increasing their severity acts at both sites.

The correlation between mitral and tricuspid nodular thickening and pulmonary disease suggests that this factor may be hypoxia. Severe pulmonary disease increases the work of both ventricles (Altschule, 1962) and changes in the left side of the heart are, therefore, not as unexpected as might at first appear. This increased work is determined by hypoxia (Mack and Snider, 1956), and while genetic variation in endothelial reactivity cannot be excluded, hypoxia affecting collagen formation is a more probable mechanism. There is experimental support for this hypothesis in the nodular thickenings induced in rat heart valves by anoxia (Dalton et al., 1945; Highman and Altland, 1949). These lesions occurred in the distal part of the valve, were most conspicuous in the mitral valves, and resembled those of human nodular sclerosis, and it is therefore likely that the pathogenesis is also the same in both species.

\section{SUMMARY}

The pathology and pathogenesis of nodular "senile" sclerosis of the atrio-ventricular valves has been studied.
At least a slight nodularity was found at the line of closure of all adult mitral valves. The degree of thickening increased throughout middle age in both atrio-ventricular valves, but showed little further progression in the elderly. It differed widely between people of the same age-group, and the normal appearances, even over 85 years, consisted of slight nodular thickening of the mitral valve only. The location and histology of the thickened foci indicated that they were a response to repeated impact, analogous to cutaneous callus formation. There was no associated endocarditis or atherosclerosis.

Excessive nodular thickening was not related to senility, systemic hypertension, cardiac hypertrophy, or multiparity, but chronic pulmonary disease was associated with a significantly increased degree of thickening in both atrio-ventricular valves.

Abnormal degrees of nodular thickening appear to result from an abnormal response of valvular endothelium. Although genetic factors cannot be excluded, it is suggested that in man, as in rats, hypoxia is important in the pathogenesis of nodular sclerosis of the atrio-ventricular valves.

I am grateful to Dr. Richard Doll for advice on the statistical aspects of this investigation, and to Dr. R. A. B. Drury for his continued support and provision of laboratory facilities. Thanks are also due to the staff of the Histopathology Department for the extra technical work involved, to Mr. A. Booker and Miss D. Haglund for the photography, and to Dr. D. Trevan for the photomicrography.

\section{REFERENCES}

Altschule, M. D. (1962). Cor pulmonale: A disease of the whole heart. Dis. Chest, 41, 398.

Angrist, A. (1964). Ageing heart valves and a unitary pathological hypothesis for sclerosis. F. Geront., 19, 135.

Clarke, J. A. (1965). An X-ray microscopic study of the blood supply to the valves of the human heart. Brit. Heart $\mathcal{F}$., 27, 420.

Dalton, A. J., Jones, B. F., Peters, V. B., and Mitchell, E. R. (1945). Organ changes in rats exposed repeatedly to lowered oxygen tension with reduced barometric pressure. F. nat. Cancer Inst., 6, 161.

Dmitrieva, V. S. (1961). Compensatory sclerosis of the cardiac valves in certain diseases. Tr. Kursk. Med. Inst., 15, 369. [Abstracted in Excerpta med. (Amst.), Sect. XVIII, 1962, 6, 727-728.]

Dock, W. (1945). Further evidence for the purely valvular origin of the first and third heart sounds. Amer. Heart f., 30, 332.

Gavey, C. J. (1949). The cardiology of old age. Lancet, $2,725$.

Gould, S. E. (1960). Pathology of the Heart, 2nd ed., p. 554. C. C. Thomas, Springfield, Illinois.

Highman, B., and Altland, P. D. (1949). Acclimatization response and pathologic changes in rats at an altitude of 25,000 feet. Arch. Path., 48, 503. 
Lapin, B. A., and Yakovleva, L. A. (1963). Comparative Pathology in Monkeys, p. 167. C. C. Thomas, Springfield, Illinois.

Lepeschkin, E. (1952). On the relation between the site of valvular involvement in endocarditis and the blood pressure on resting on the valve. Amer. F. med. Sci., $224,318$.

Mack, I., and Snider, G. L. (1956). Respiratory insufficiency and chronic cor pulmonale. Circulation, 13, 419.

McMillan, J. B., and Lev, M. (1964). The aging heart: II, The valves. F. Geront., 19, 1.

Master, A. M., Lasser, R. P., and Jaffe, H. L. (1958). Blood pressure in white people over 65 years of age. Ann. intern. Med., 48, 284.

Pomerance, A. (1966). Atheroma of the mitral valve. $\mathcal{f}$. Atheroscler. Res. In the press.
(1967). Ageing changes in human heart valves. Brit. Heart $\mathcal{F}$. In the press.

Rezek, P. R., and Millard, M. (1963). Autopsy Pathology, p. 260. C. C. Thomas, Springfield, Illinois.

Robbins, S. L. (1962). Textbook of Pathology with Clinical Application, 2nd ed., p. 397. W. B. Saunders, Philadelphia and London.

Rodbard, S. (1963). Blood velocity and endocarditis. Circulation, 27, 18.

Rosenthal, J., and Feigin, I. (1947). Pathology of the mitral valve in the older age groups. Amer. Heart f., 33, 346.

Verzár, F., and Thoenen, H. (1960). Die Wirkung von Elektrolyten auf die thermische Kontraktion von Collagenfäden. Gerontologia (Basel), 4, 112.

Wood, P. (1962). Diseases of the Heart and Circulation, 2nd ed., p. 63. Eyre and Spottiswoode, London. 